\title{
LONG-TERM CLINICAL RESULTS FOR RANDOMISED COMPARISON OF PACLITAXEL-ELUTING VERSUS BARE-METAL STENTS IN UNPROTECTED LEFT MAIN CORONARY ARTERY DISEASE
}

\author{
Inga Narbute, Sanda Jēgere, Indulis Kumsārs, Iveta Mintāle, Ilja Zakke, Dace Juhnēviča, \\ Kārlis Trušinskis, Dace Sondore, Aigars Lismanis, Gustavs Latkovskis, Alına Grāve, \\ Andis Dombrovskis, and Andrejs Ërglis
}

\author{
Latvian Centre of Cardiology, Pauls Stradiṇš Clinical University Hospital, Pilsoṇu iela 13, Rīga, LV-1002, LATVIA \\ Email: inga.narbute@stradini.lv
}

Contributed by Andrejs Ërglis

\begin{abstract}
To optimise percutaneous coronary intervention (PCI) strategy for unprotected left main (ULMCA) disease we performed a randomised study: IVUS-guided bare metal stent (BMS) versus paclitaxel-eluting stent (PES) implantation after lesion pre-treatment with cutting balloon (CB) for unprotected LM lesions. The purpose of this randomized study was to evaluate six-month and three-year clinical results. Several recent publications have demonstrated good short- and midterm outcomes in patients with left main artery disease after stent implantation. However, data on long-term comparison of BMS and PES for LM lesions are limited. Patients with left main coronary artery disease enrolled at Latvian Centre of Cardiology were randomly assigned to either BMS $(n=50)$ or PES implantation $(n=53)$. All interventions were IVUS-guided and CB pretreatment before stenting was performed in all patients. All patients were scheduled for six-month and three-year follow-up. The primary endpoint was major adverse cardiac events (MACE) defined as death, $Q$ wave myocardial infarction or target lesion revascularisation (TLR). Baseline clinical and procedural characteristics were comparable in both groups. At six months, the MACE-free survival rate was $70 \%$ in BMS and $87 \%$ in PES patients $(P<0.05)$. At three years, MACE occurred in 18 patients (36.0\%) in the BMS and seven patients (13.2\%) in the PES group $(P<0.05)$. The current study demonstrates the benefit of IVUS guided paclitaxel-eluting stent implantation after cutting balloon pre-treatment in left main coronary artery disease over bare metal stent implantation at six months and three years.
\end{abstract}

Key words: drug-eluting stents, paclitaxel, left main stenting, long-term.

\section{INTRODUCTION}

Although coronary artery bypass grafting $(\mathrm{CABG})$ is the gold standard for the treatment of the unprotected left main coronary artery (ULMCA) disease (Smith et al., 2006), many patients are currently undergoing percutaneous coronary intervention (PCI). Initial studies of balloon angioplasty for ULMCA disease had poor early and long-term results (O'Keefe et al., 1989; Eldar et al., 1991). Bare-metal stents (BMS) reduced procedural complications, however rates of repeat revascularisation because of restenosis remained high (Tan et al., 2001; Takagi et al., 2002; Park et al., 1998; Silvestri et al., 2000). Recent progress in interventional cardiology, including the use of drug-eluting stents (DES), intravascular ultrasound (IVUS) imaging, debulking before stenting and effective antiplatelet agents, have resulted in decreased restenosis rate (Abizaid et al., 1999; Park et al., 2001).
Several recent publications have demonstrated superior short- and mid-term outcomes in patients with left main artery disease after DES versus BMS implantation (Park et al., 2005; Erglis et al., 2007) and similar survival rates after DES versus CABG (Lee et al., 2006; Palmerini et al., 2007; 2006; Sanmartin et al., 2007; White et al., 2008). The main restriction is that long-term data with both BMS and DES in this subset of patients are limited (Valgimigli et al., 2005; Chieffo et al., 2007; Buszman et al., 2008; Meliga et al., 2008; Palmerini et al., 2008; Seung et al., 2008; White et al., 2008) Moreover, some reports have raised concern about incomplete or delayed neointimal coverage of DES with a subsequent increase in late stent thrombosis (Joner et al., 2006).

Therefore, in a randomised study we evaluated IVUSguided BMS and paclitaxel-eluting stent (PES) implantation after lesion pre-treatment with cutting balloon (CB) for 
ULMCA stenosis. The purpose of this study was to determine whether PES is superior to BMS during long-term clinical follow-up.

\section{MATERIALS AND METHODS}

Starting from February 2004, 103 patients with ULMCA disease were randomly assigned to receive bare metal Express or Liberte stent $(\mathrm{n}=50)$ or Taxus Express paclitaxeleluting stent $(\mathrm{n}=53)$ (Boston Scientific Corporation, Natick, Massachussetts, USA). Patients were eligible for the study if they had stable or unstable angina pectoris, or silent ischemia, 50\% diameter stenosis of ULMCA which could be treated with stent implantation. All patients were good candidates for CABG. Major exclusion criteria included coronary artery bypass grafts to left anterior descending (LAD) or left circumflex artery branches, life expectancy less than one year or planned non-cardiac surgery in six months. Informed written consents were obtained for all patients.

\section{PCI procedure}

Medical protocol. All patients undergoing PCI were pretreated with dual anteplatelet therapy: aspirin $(100 \mathrm{mg})$ and clopidogrel (loading dose, $300 \mathrm{mg}$ ). After the procedure clopidogrel was recommended for at least six months, while aspirin - lifelong. Low-molecular-weight heparin or unfractionated heparin was administered in the catheterisation lab depending on the patients weight. Glycoprotein (GP) IIb/IIIa receptor inhibitors were given at the operator's discretion.

All interventions were performed using IVUS guidance and cutting balloon pre-treatment for atherosclerotic plaque modification before stenting.

Cutting balloon intervention. CB intervention was performed with a balloon-to-vessel ratio of $1: 1$, according to the IVUS media-to-media to the vessel at the lesion site. CB intervention was performed to cover the entire lesion length. Balloon inflations were performed three times with increasing pressure throughout the lesion.

Stent implantation. All lesions at the ostium and body were treated with a single stent implantation. If the distal portion of the LM or a bifurcation was involved, the following stenting strategies were used: stenting across the LCX ostium or provisional $\mathrm{T}$ stenting (if the LCX ostium and/or proximal part were severely diseased). Final kissing balloon dilatation was performed only in cases with suboptimal result at the LCX ostium. In other cases a good result was achieved by opening the stent strut to the LCX with a small diameter balloon or just after stent implantation.

After stent implantation subsequent IVUS was performed to evaluate stent apposition and residual stenosis. If any segment on the treated vessel did not meet success criteria, ad- ditional balloon dilatations with a non-compliant (NC) balloon were performed.

Follow-up. Patients were asked to return for clinical follow-up to assess adverse events and to perform stress testing at one, three, six, and twelve months, and then annually thereafter. Follow-up angiography with quantitative coronary angiography and intravascular ultrasound was performed at six months and three years. At three years, angiographic and IVUS follow-up was performed in all patients alive who did not experience target vessel revascularisation during six months follow-up and did not refuse to undergo the procedure.

Definitions. The primary endpoint of the study was major adverse cardiac event (MACE) - free survival. MACE was defined as the occurrence of death, Q-wave myocardial infarction, or target lesion revascularisation during the followup period. Patients with more than one event were assigned to the highest rank event. Death was defined as death from any cause. All deaths were considered to be of cardiac origin unless a non-cardiac origin was diagnosed. Q-wave myocardial infarction was defined as documentation of a new abnormal Q wave after the index treatment. Target lesion revascularisation (TLR) was defined as any repeat surgical or percutaneous intervention to treat a luminal stenosis in the stent or within the $5-\mathrm{mm}$ segment adjacent to the stent, including the ostium of the left anterior descending artery and/or circumflex artery. Procedural success was defined as minimum lumen area $\geq 9.0 \mathrm{~mm}^{2}$ by IVUS, or residual angiographic stenosis $<10 \%$ (if the minimal luminal reference vessel size by IVUS was smaller than $9.0 \mathrm{~mm}^{2}$ ).

Statistics. Statistical analyses were performed using SPSS 12.0 for Windows (SPSS Inc., Chicago, IL, USA). Continuous variables are presented as mean \pm standard deviation and compared using an unpaired Student's t-test or MannWhitney rank-sum test, depending on variable distribution. Categorical variables were compared by $\chi^{2}$ statistics or Fisher's exact test as appropriate. All statistical tests were 2 -sided, and a $P$ value 0.05 was considered statistically significant. Major adverse cardiac event-free survival was examined by Kaplan-Meyer analysis and differences between groups were determined by log-rank test.

\section{RESULTS}

A total of 103 patients with ULMCA disease underwent IVUS-guided PCI with PES $(n=53)$ or BMS $(n=50)$ implantation after cutting balloon pretreatment.

Baseline clinical, lesion and procedural characteristics of the study population are published elsewhere (Erglis et al., 2007). Overall there were no significant differences in baseline characteristics except for significantly longer mean stent length, shorter mean stent diameter and higher maximal stent implantation pressure in the group treated with PES. Coronary lesion complexity was similar in both groups, with Syntax Score 31.4 \pm 14.5 in BMS and $32.6 \pm$ 


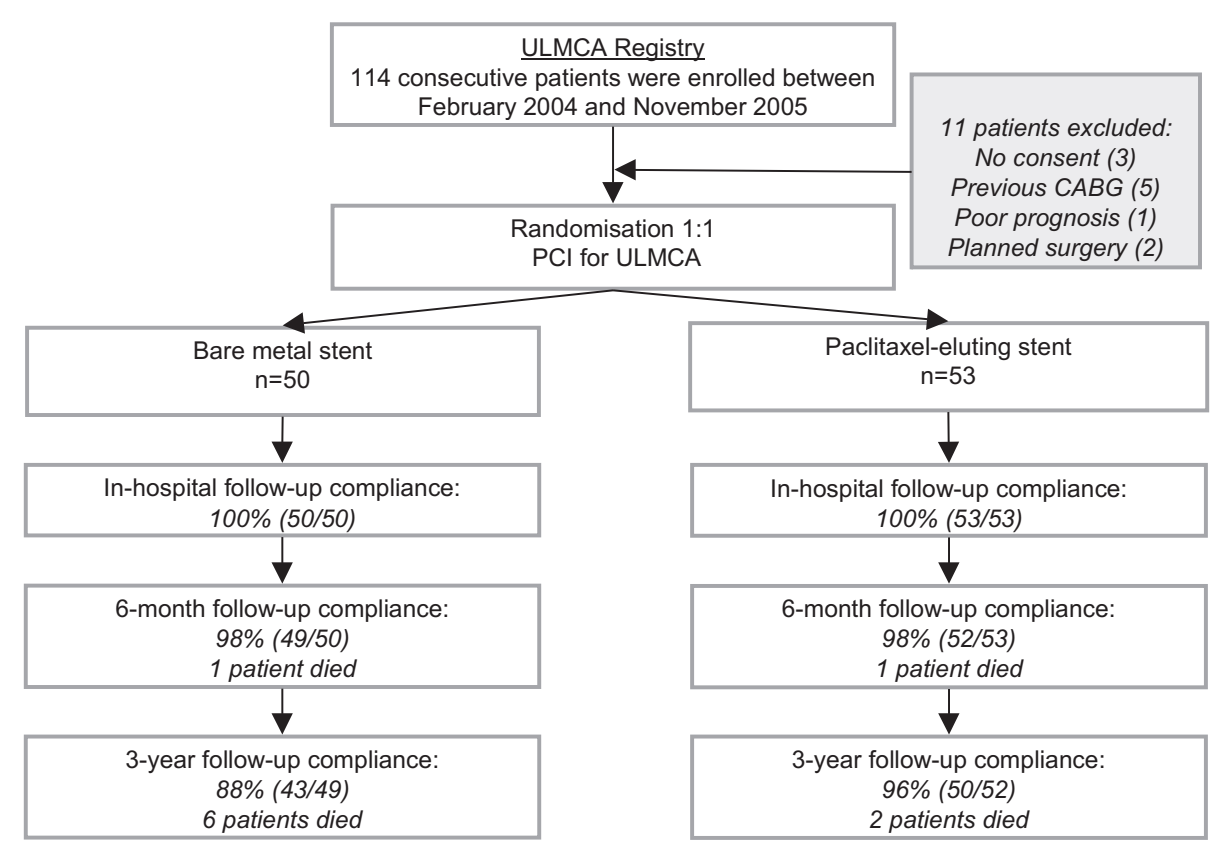

Fig. 1. Flow of patients through the trial.

11.7 in PES patients $(P>0.05)$. The procedural success was $100 \%$ in both groups.

Clinical follow-up. The flow of patients through the trial is shown in Figure 1. A total of 93 patients completed clinical long-term follow-up. During this time period $(906 \pm 346$ days) seven (14.0\%) patients in the BMS and $3(5.7 \%)$ patients in the PES group $(P<0.05)$ died. Four patients $(8.0 \%)$ in the BMS group and three patients $(5.7 \%)$ in the PES group $(P>0.05)$ died from cardiac cause. Non-cardiac deaths in BMS-group patients consisted of lung cancer, stomach cancer and non-Hodgkin lymphoma. No patient was lost to follow-up. During this follow-up period only one patient $(2.0 \%)$ in the BMS group and three patients $(5.7 \%)$ in the PES group experienced Q-wave myocardial infarction $(P>0.05)$. No cases of definite or probable stent thrombosis were observed. Ten patients $(20.0 \%)$ in the BMS group underwent TLR - nine repeat PCI and one $\mathrm{CABG}$, in contrast, only $3(5.7 \%)$ patients in the PES group needed repeat PCI $(P<0.05)$. MACE at follow-up occurred

\section{Table 1}

CUMULATIVE CLINICAL OUTCOMES AT THREE-YEAR FOLLOW-UP

\begin{tabular}{l|c|c|c|c}
\hline & $\begin{array}{c}\text { BMS } \\
(\mathrm{n}=50)\end{array}$ & $\begin{array}{c}\text { PES } \\
(\mathrm{n}=53)\end{array}$ & $P$ value & $\begin{array}{c}\text { All } \\
(\mathrm{n}=103)\end{array}$ \\
\hline Total death, n (\%) & $7(14.0)$ & $3(5.7)$ & $>0.05$ & $10(9.7)$ \\
Cardiac death, n (\%) & $4(8.0)$ & $3(5.7)$ & $>0.05$ & $7(6.8)$ \\
Q-MI, n (\%) & $1(2.0)$ & $3(5.7)$ & $>0.05$ & $4(3.9)$ \\
TLR, n (\%) & $10(20.0)$ & $3(5.7)$ & $<0.05$ & $13(12.6)$ \\
TLR-PCI, n (\%) & $9(18.0)$ & $3(5.7)$ & $>0.05$ & $12(1.7)$ \\
TLR-CABG, n (\%) & $1(2.0)$ & $0(0)$ & $>0.05$ & $1(1.0)$ \\
Total MACE, n (\%) & $18(36.0)$ & $7(13.2)$ & 0.011 & $25(24.3)$
\end{tabular}

BMS, bare metal stent; PES, paclitaxel-eluting stent; Q-MI, Q wave myocardial infarction; TLR, target lesion revascularisation; PCI; percutaneous coronary intervention; $\mathrm{CABG}$, coronary artery bypass grafting; MACE, major adverse cardiac events in $18(36.0 \%)$ and $7(13.2 \%)$ patients in the BMS and PES groups, respectively $(P=0.011)$. Cumulative clinical outcomes at three-year follow-up are summarised in Table 1 and Figure 2.

\section{DISCUSSION}

The main finding of this randomised long-term follow-up study is that both PES and BMS implantation are safe and feasible in patients with ULMCA stenosis. The benefit of PES implantation was observed up to three years at clinical follow-up with an acceptably low incidence of recurrent events, $5.7 \%$ of total and $5.7 \%$ of cardiac death in the PES

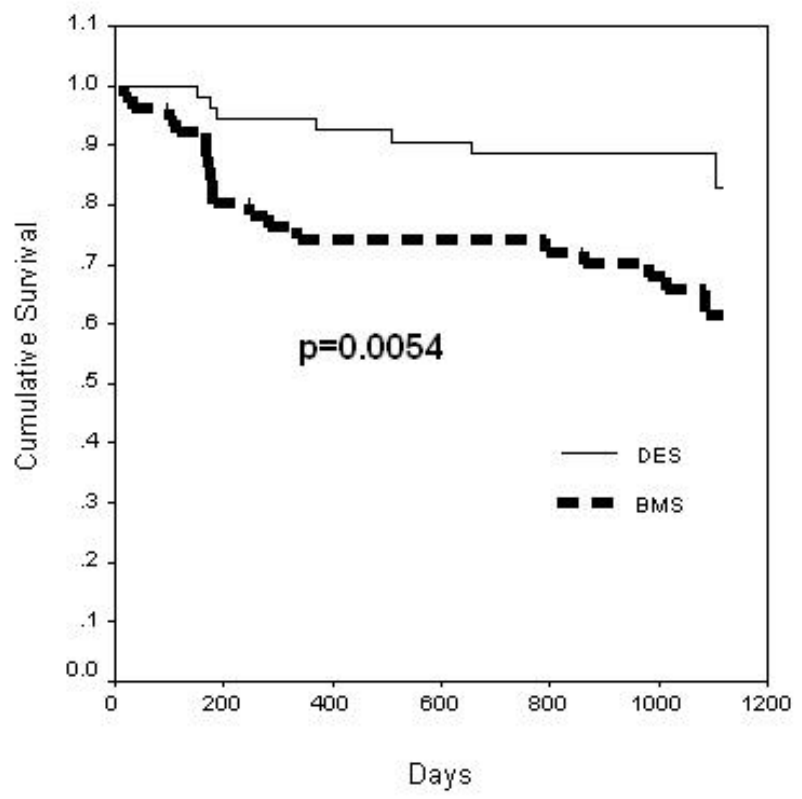

Fig. 2. Kaplan-Meier curves: freedom from death, Q-myocardial infarction and target lesion revascularisation. At three years, the Major Adverse Cardiac Event (MACE) - free survival rate was $75.7 \%$ in the study population, $64.0 \%$ in the BMS group and $86.8 \%$ in the PES group $(P=0.0054)$. 
group compared with $14.0 \%$ of the total and $8.0 \%$ of cardiac death in the BMS group and with the overall incidence of MACE $13.2 \%$ and $36.0 \%(P=0.011)$ in the PES and BMS subgroups, respectively. Regarding death rate, we have to consider natural ageing of the patients (at enrolment stage mean ages were $62.56 \pm 11.45$ in BMS group and $61.08 \pm 10.28$ PES group). At three years follow-up the oldest patient was already 89 years old.

There is little information from long-term follow-up studies regarding the efficacy of drug-eluting stents in patients with lesions located at the left main (Buszman et al., 2008; Meliga et al., 2008; Palmerini et al., 2008; Seung et al., 2008) with especially scarce long-term data available from angiographic studies (Valgimigli et al., 2005; Chieffo et al., 2007).

DES vs BMS. Palmerini et al. (2008) recently published a two-year clinical follow-up with DES versus BMS in a real-world registry of ULMCA. This multicentre observational study showed promising results with two-year survival and survival free from cardiac death rates of $90.1 \%$ and $93.1 \%$ in the DES group and $75.9 \%$ and $82.4 \%$ in the BMS group $(P<0.001)$. Gao et al. (2008) showed that the cumulative MACE rate at 15 months was significantly decreased in the elective patients $(n=220)$ who received DES $(9.5 \%)$ as compared with patients $(\mathrm{n}=224)$ treated with BMS $(16.5 \%, P<0.05)$ derived from Chinese registry of unprotected LM stenting, despite the fact that more complex patients and lesions were included in the DES group. These data are consistent with our study.

Stents vs CABG long term outcomes. The first randomised trial (the LE MANS study) of $52 \mathrm{PCI}$ (35\% with DES) and $53 \mathrm{CABG}$ patients showed that major adverse cardiac and cerebral event (MACCE) - free one-year survival was similar in both groups $(71.2 \%$ PCI vs. $75.5 \%$ CABG, $P>$ $0.05)$ where MACCE was defined as cardiac death, acute myocardial infarction, stroke, repeat intervention, in-stent thrombosis (Buszman et al., 2008). Data from the largest on-going prospective multicentre randomised SYNTAX trial (Serruys et al., 2009) of 705 patients with ULMCA showed that overall MACCE (death, myocardial infarction, stroke, repeat revascularisation) at one year follow-up in the PCI group was comparable with CABG (15.8\% PES vs. $13.6 \% \mathrm{CABG}$ ). PCI outcomes were excellent relative to CABG in LM isolated and LM plus one vessel disease, but were not statistically different. The PES cohort of our study showed comparable results with the SYNTAX 1 year MACCE data. Long-term data of the SYNTAX trial are awaited, while the LE MANS study showed similar MACCE-free survival during a $28.8 \pm 9.9$ month follow-up in both groups (53.9.2\% PCI vs. 56.6\% CABG, $P>0.05)$. Despite the intermediate SYNTAX score in the LE MANS study and our study (25.2\% and $32.0 \%$, respectively) MACCE-free survival was lower in our study $-75.7 \%$ of MACE in both BMS and DES patients at three-year follow up.
Despite the large number of patients with distal LM stenosis (81\% in PES and 68\% in DES) and high Syntax Scores $(32.6 \%$ and $31.3 \%$, respectively) in our study, low incidence of MACE at three-year follow-up, especially in PES group (13.2\%), compared with other studies were achieved. We tend to claim that it could be reached due to $100 \%$ use of plaque debulking with cutting balloon as well as $100 \%$ of IVUS guidance in stenting procedure. However, a randomised trial of unprotected LM stenting with CB plague modification versus without debulking as well as with IVUS guidance versus without one are required to establish benefits from those techniques.

In conclusion, based on the results of our study, patients with unprotected left main disease treated with paclitaxeleluting stents using cutting balloon plague pre-treatment and IVUS guidance have favourable late outcomes in comparison with bare metal stents.

The results of long-term follow-up demonstrates significant benefit for paclitaxel-eluting stents versus bare metal stents in terms of clinical results.

\section{ACKNOWLEDGMENT}

The work was supported by the National Research Programme in Medicine 2006-2009, project No. 1, „Elaboration of new methods of early diagnostics, prevention and treatment of cardiovascular diseases". We gratefully acknowledge the Innovative Medical Foundation for providing financial support. We gratefully acknowledge Andris Eglitis for his permanent support and technical assistance. We also would like to thank Andris Saltups for helpful discussions and advices.

\section{REFERENCES}

Abizaid, A.S., Mintz, G.S., Abizaid, A., Mehran, R., Lansky, A.J., Pichard, A.D., Satler, L.F., Wu, H., Kent, K.M., Leon, M.B. (1999). One-year follow-up after intravascular ultrasound assessment of moderate left main coronary artery disease in patients with ambiguous angiograms. J. Amer. Coll. Cardiol., 34(3), 707-715.

Buszman, P.E., Kiesz, S.R., Bochenek, A., Peszek-Przybyla, E., Szkrobka, I., Debinski, M., Bialkowska, B., Dudek, D., Gruszka, A., Zurakowski, A., Milewski, K., Wilczynski, M., Rzeszutko, L., Buszman, P., Szymszal, J., Martin, J.L., Tendera, M. (2008). Acute and late outcomes of unprotected left main stenting in comparison with surgical revascularization. J. Amer. Coll. Cardiol., 51(5), 538-545.

Chieffo, A., Park, S.J., Valgimigli, M., Kim, Y.H., Daemen, J., Sheiban, I., Truffa, A., Montorfano, M., Airoldi, F., Sangiorgi, G., Carlino, M., Michev, I., Lee, C.W., Hong, M.K., Park, S.W., Moretti, C., Bonizzoni, E., Rogacka, R., Serruys, P.W., Colombo, A. (2007). Favorable long-term outcome after drug-eluting stent implantation in nonbifurcation lesions that involve unprotected left main coronary artery: A multicenter registry. Circulation, 116(2), 158-162.

Eldar, M., Schulhoff, N., Herz, I., Frankel, R., Feld, H., Shani, J. (1991). Results of percutaneous transluminal angioplasty of the left main coronary artery. Amer. J. Cardiol., 68(2), 255-256.

Erglis, A., Narbute, I., Kumsars, I., Jegere, S., Mintale, I., Zakke, I., Strazdins, U., Saltups, A. (2007). A randomized comparison of paclitaxeleluting stents versus bare-metal stents for treatment of unprotected left main coronary artery stenosis. J. Amer. Coll. Cardiol., 50(6), 491-497. 
Gao, R.L., Xu, B., Chen, J.L., Yang, Y.J., Qiao, S.B., Li, J.J., Qin, X.W., Yao, M., Liu, H.B., Wu, Y.J., Yuan, J.Q., Chen, J. (2008). Immediate and long-term outcomes of drug-eluting stent implantation for unprotected left main coronary artery disease: Comparison with bare-metal stent implantation. Amer. Heart J., 155(3), 553-561.

Joner, M., Finn, A.V., Farb, A., Mont, E.K., Kolodgie, F.D., Ladich, E., Kutys, R., Skorija, K., Gold, H.K., Virmani, R. (2006). Pathology of drug-eluting stents in humans: Delayed healing and late thrombotic risk. $J$. Amer. Coll. Cardiol., 48(1), 193-202.

Lee, M.S., Kapoor, N., Jamal, F., Czer, L., Aragon, J., Forrester, J., Kar, S., Dohad, S., Kass, R., Eigler, N., Trento, A., Shah, P.K., Makkar, R.R. (2006). Comparison of coronary artery bypass surgery with percutaneous coronary intervention with drug-eluting stents for unprotected left main coronary artery disease. J. Amer. Coll. Cardiol., 47(4), 864-870.

Meliga, E., Garcia-Garcia, H.M., Valgimigli, M., Chieffo, A., BiondiZoccai, G., Maree, A.O., Cook, S., Reardon, L., Moretti, C., De Servi, S., Palacios, I.F., Windecker, S., Colombo, A., van Domburg, R., Sheiban, I., Serruys, P.W. (2008). Longest available clinical outcomes after drugeluting stent implantation for unprotected left main coronary artery disease: The DELFT (Drug Eluting stent for LeFT main) Registry. J. Amer. Coll. Cardiol., 51(23), 2212-2219.

O'Keefe, J.H., Jr., Hartzler, G.O., Rutherford, B.D., McConahay, D.R., Johnson, W.L., Giorgi, L.V., Ligon, R.W. (1989). Left main coronary angioplasty: Early and late results of 127 acute and elective procedures. Amer. J. Cardiol., 64(3), 144-147.

Palmerini, T., Barlocco, F., Santarelli, A., Bacchi-Reggiani, L., Savini, C., Baldini, E., Alessi, L., Ruffini, M., Di Credico, G., Piovaccari, G., Di Bartolomeo, R., Marzocchi, A., Branzi, A., De Servi, S. (2007). A comparison between coronary artery bypass grafting surgery and drug eluting stent for the treatment of unprotected left main coronary artery disease in elderly patients (aged -75 years). Eur. Heart J., 28(22), 2714-2719.

Palmerini, T., Marzocchi, A., Marrozzini, C., Ortolani, P., Saia, F., Savini, C., Bacchi-Reggiani, L., Gianstefani, S., Virzi, S., Manara, F., Kiros Weldeab, M., Marinelli, G., Di Bartolomeo, R., Branzi, A. (2006). Comparison between coronary angioplasty and coronary artery bypass surgery for the treatment of unprotected left main coronary artery stenosis (the Bologna Registry). Amer. J. Cardiol., 98(1), 54-59.

Palmerini, T., Marzocchi, A., Tamburino, C., Sheiban, I., Margheri, M., Vecchi, G., Sangiorgi, G., Santarelli, A., Bartorelli, A., Briguori, C., Vignali, L., Di Pede, F., Ramondo, A., Inglese, L., De Carlo, M., Bolognese, L., Benassi, A., Palmieri, C., Filippone, V., Sangiorgi, D., De Servi, S. (2008). Two-year clinical outcome with drug-eluting stents versus bare-metal stents in a real-world registry of unprotected left main coronary artery stenosis from the Italian Society of Invasive Cardiology. Amer. J. Cardiol., 102(11), 1463-1468.

Park, S.-J., Hong, M.-K., Lee, C.W., Kim, J.-J., Song, J.-K., Kang, D.-H., Park, S.-W., Mintz, G.S. (2001). Elective stenting of unprotected left main coronary artery stenosis: Effect of debulking before stenting and intravascular ultrasound guidance. J. Amer. Coll. Cardiol., 38(4), 1054-1060.

Park, S.J., Kim, Y.H., Lee, B.K., Lee, S.W., Lee, C.W., Hong, M.K., Kim, J.J., Mintz, G.S., Park, S.W. (2005). Sirolimus-eluting stent implantation for unprotected left main coronary artery stenosis: Comparison with bare metal stent implantation. J. Amer. Coll. Cardiol., 45(3), 351-356.

Park, S.J., Park, S.W., Hong, M.K., Cheong, S.S., Lee, C.W., Kim, J.J., Hong, M.K., Mintz, G.S., Leon, M.B. (1998). Stenting of unprotected left main coronary artery stenoses: Immediate and late outcomes. J. Amer. Coll. Cardiol., 31(1), 37-42.

Sanmartin, M., Baz, J.A., Claro, R., Asorey, V., Duran, D., Pradas, G., Iniguez, A. (2007). Comparison of drug-eluting stents versus surgery for unprotected left main coronary artery disease. Amer. J. Cardiol., 100(6), 970-973.

Serruys, P.W., Morice, M.-C., Kappetein, A.P., Colombo, A., Holmes, D.R., Mack, M.J., Stahle, E., Feldman, T.E., van den Brand, M., Bass, E.J., Van Dyck, N., Leadley, K., Dawkins, K.D., Mohr, F.W. (2009). Percutaneous coronary intervention versus coronary-artery bypass grafting for severe coronary artery disease. New Engl. J. Med., 360(10), 961-972.

Seung, K.B., Park, D.-W., Kim, Y.-H., Lee, S.-W., Lee, C.W., Hong, M.-K., Park, S.-W., Yun, S.-C., Gwon, H.-C., Jeong, M.-H., Jang, Y., Kim, H.-S., Kim, P.J., Seong, I.-W., Park, H.S., Ahn, T., Chae, I.-H., Tahk, S.-J., Chung, W.-S., Park, S.-J. (2008). Stents versus coronary-artery bypass grafting for left main coronary artery disease. New Engl. J. Med., 358(17), 1781-1792.

Silvestri, M., Barragan, P., Sainsous, J., Bayet, G., Simeoni, J.-B., Roquebert, P.-O., Macaluso, G., Bouvier, J.-L., Comet, B. (2000). Unprotected left main coronary artery stenting: Immediate and medium-term outcomes of 140 elective procedures. J. Amer. Coll. Cardiol., 35(6), $1543-1550$.

Smith, S.C., Jr., Feldman, T.E., Hirshfeld, J.W., Jr., Jacobs, A.K., Kern, M.J., King, S.B., III, Morrison, D.A., O'Neill, W.W., Schaff, H.V., Whitlow, P.L., Williams, D.O., Antman, E.M., Smith, S.C., Jr., Adams, C.D., Anderson, J.L., Faxon, D.P., Fuster, V., Halperin, J.L., Hiratzka, L.F., Hunt, S.A., Jacobs, A.K., Nishimura, R., Ornato, J.P., Page, R.L., Riegel, B. (2006). ACC/AHA/SCAI 2005 Guideline update for percutaneous coronary intervention. Summary article: A report of the American College of Cardiology/American Heart Association Task Force on Practice Guidelines (ACC/AHA/SCAI Writing Committee to Update the 2001 Guidelines for Percutaneous Coronary Intervention). Circulation, 113(1), 156-175.

Takagi, T., Stankovic, G., Finci, L., Toutouzas, K., Chieffo, A., Spanos, V., Liistro, F., Briguori, C., Corvaja, N., Albero, R., Sivieri, G., Paloschi, R., Di Mario, C., Colombo, A. (2002). Results and long-term predictors of adverse clinical events after elective percutaneous interventions on unprotected left main coronary artery. Circulation, 106(6), 698-702.

Tan, W.A., Tamai, H., Park, S.-J., Plokker, H.W.T., Nobuyoshi, M., Suzuki, T., Colombo, A., Macaya, C., Holmes, D.R., Jr., Cohen, D.J., Whitlow, P.L., Ellis, S.G. (2001). Long-term clinical outcomes after unprotected left main trunk percutaneous revascularization in 279 patients. Circulation, 104(14), 1609-1614.

Valgimigli, M., van Mieghem, C.A.G., Ong, A.T.L., Aoki, J., Granillo, G.A.R., McFadden, E.P., Kappetein, A.P., de Feyter, P.J., Smits, P.C., Regar, E., Van der Giessen, W.J., Sianos, G., de Jaegere, P., Van Domburg, R.T., Serruys, P.W. (2005). Short- and long-term clinical outcome after drug-eluting stent implantation for the percutaneous treatment of left main coronary artery disease: Insights from the rapamycin-eluting and taxus stente evaluated at Rotterdam Cardiology Hospital Registries (RESEARCH and T-SEARCH). Circulation, 111(11), 1383-1389.

White, A.J., Kedia, G., Mirocha, J.M., Lee, M.S., Forrester, J.S., Morales, W.C., Dohad, S., Kar, S., Czer, L.S., Fontana, G.P., Trento, A., Shah, P.K., Makkar, R.R. (2008). Comparison of coronary artery bypass surgery and percutaneous drug-eluting stent implantation for treatment of left main coronary artery stenosis. J. Amer. Coll. Cardiol. Intv., 1(3), 236-245. 


\section{AR PAKLITAKSELU PILDĪTA STENTA VAI PARASTA METĀLA STENTA IMPLANTĀCIJA NEPROTEKTĒTĀ KREISĀS KORONĀRĀS ARTĒRIJAS KOPĒJĀ STUMBRA BOJĀJUMĀ: ILGTERMIN̦A KLİNISKO REZULTĀTU RANDOMIZĒTS SALĪDZINĀJUMS}

Lai optimizētu perkutānās koronārās intervences stratēǵiju neprotektētiem kreisās koronārās artērijas kopējā stumbra bojājumiem, veicām randomizētu pētījumu: intravaskulārās ultraskaņās (IVUS) kontrolētu parasta metāla stentu (BMS) un ar paklitakselu pildītu stentu (PES) implantācijas salīdzinājumu, pēc aterosklerotiskās plāksnes sagatavošanas ar griezošo balonu. Pētījuma mērḳis bija apsekot pacientus pēc sešiem mēnešiem un trim gadiem, vērtējot viṇu klīnisko stāvokli. Vairāki nesen publicēti ziṇojumi demonstrējuši labus īstermiṇa un vidēja termiņa rezultātus pacientiem pēc stentu implantācijas kreisās koronārās artērijas kopējā stumbra bojājumos. Tomēr dati par parasta metāla stentu un ar paklitakselu pildītu stentu ilgtermiņa rezultātiem šai pacientu kohortai ir limitēti. Randomizējām Latvijas Kardiolog̣ijas centra pacientus ar kreisās koronārās artērijas kopējā stumbra aterosklerotiskiem bojājumiem BMS (n = 50) vai PES (n = 53) stentu implantācijai. Visas koronārās intervences bija IVUS kontrolētas, visiem pacientiem pirms stenta implantācijas aterosklerotisko plāksni sagatavoja ar griezošo balonu. Visiem pacientiem nozīmēta sešu mēnešu un trīs gadu apsekošana. Primārais beigu punkts bija liels kardiāls nelabvēlīgs notikums, ko definēja kā nāvi, Q miokarda infarktu vai mērḳa bojājuma atkārtotu intervenci. Vispārējie pacientu un procedūras parametri bija salīdzināmi abās grupās. Pēc sešiem mēnešiem lielos nelabvēlīgos kardiālos notikumus nebija piedzīvojuši 70\% BMS un $87 \%$ PES grupas pacienti $(P<0,05)$. Trīs gados lielos nelabvēlīgos kardiālos notikumus bija piedzīvojuši 18 BMS pacienti $(36,0 \%)$ un septiṇi PES pacienti $(13,2 \%)(P<0,05)$. Mūsu pētījuma sešu mēnešu un trīs gadu apsekošanas rezultāti pierādījuši IVUS kontrolētu, ar paklitakselu pildītu stentu implantācijas pārākumu pār parasta metāla stentu implantāciju pacientiem ar kreisās koronārās artērijas kopējā stumbra bojājumiem, pirms stenta implantācijas bojājumu sagatavojot ar griezošo balonu. 